\title{
STRUCTURAL ANALYSIS OF TOURISM PROFIT FROM THE SOUTH-EAST DEVELOPMENT REGION, ROMANIA
}

DOI: http://dx.doi.org/10.18509/GBP.2020.76

UDC: 338.486.2:658.155]:005.52(498-12)"2000/2018"

\author{
Joița Oana-Elena ${ }^{1,2}$ \\ Olteanu Cosmin ${ }^{1,2}$ \\ Bucurică Tonia-Steluța ${ }^{1,2}$ \\ Pintilii Radu-Daniel ${ }^{1,2}$ \\ Gruia Andreea-Karina ${ }^{1,2}$ \\ ${ }^{1}$ Research Center for Integrated Analysis and Territorial \\ Management, University of Bucharest, Romania \\ ${ }^{2}$ Faculty of Geography, University of Bucharest, Bucharest, Romania
}

\begin{abstract}
The assessment of the economic performance of any economic sector can also be achieved through the structural analysis of the profit, this being the final result of the activity of a company and a measure of its efficiency. The structural analysis of tourism profit can provide us relevant information regarding the viability of this economic sector and its contribution to the local economies. In this study we intend to analyze the tourism profit from the South-East Development Region, from a structural point of view, in order to identify those tourism sectors that have the biggest contribution to the total tourism profit in this region. Thus, a tourism profit database was created for each territorial administrative unit in the South-East Development Region, at the four-digit NACE code level, for the period 2000-2018. Subsequently, the database was used to make graphical representations from an evolutionary point of view. The applied methodology highlighted a positive evolution, for the entire period analyzed, of the profit obtained from tourism in total profit achieved at the region level.
\end{abstract}

Keywords: structural analysis, profit, tourism, local development, South-East Development Region

\section{INTRODUCTION}

The profit obtained by a company is understood as that gain in money resulting from an economic activity from which the expenses are deducted, more precisely it represents the difference between income and expenses. This word comes from the Latin "proficere" which means "to progress, to give results", which means that a company cannot evolve in the absence of a profit [1]. Currently, economic development policies focus on supporting entrepreneurship, which is considered an important factor of the EU 2020 strategy as it contributes to poverty reduction and the development of local communities [2], [3]. Business development is stimulated by different economic mechanisms, considering that entrepreneurship plays an important role in increasing economic competitiveness and in creating jobs [3], [4]. Sustainable development strategies, which are based on European funds, target priority sectors such as creative industries, tourism, infrastructure, Micro, Small and Medium Enterprises, which can contribute to solving economic, social and environmental problems at local, regional or national level [5], [6], [7], [8], [9]. Tourism, one of the economic sectors that can stimulate economic 
development, has a major contribution to GDP, due to the multiplier effect, it generates jobs, it contributes to the construction of an infrastructure, all of which contribute positively to the well-being of the population [10], [11], [12]. A structural analysis of the profit registered by the companies that carry out tourism activities in the South-East Development Region of Romania can provide us with relevant information about their contribution to the local economies and implicitly about the viability of this economic sector.

The development of a tourism strategy, based on the results obtained from the research, can contribute to the development of the region from several points of view, tourism having both economic and social implications [13].

\section{METHODOLOGY}

In the present study we set out to analyze, from an evolutionary and structural point of view, the profit obtained by the companies that carry out tourism activities in the SouthEast Development Region. The South-East Development Region is composed of Brăila, Buzău, Constanța, Galați, Tulcea and Vrancea counties, being the second development region in Romania. RThe tourist resources are diversified, the most representative are the Danube Delta and the Black Sea coast, which make this region one of the main tourist destinations of the country (Figure 1).

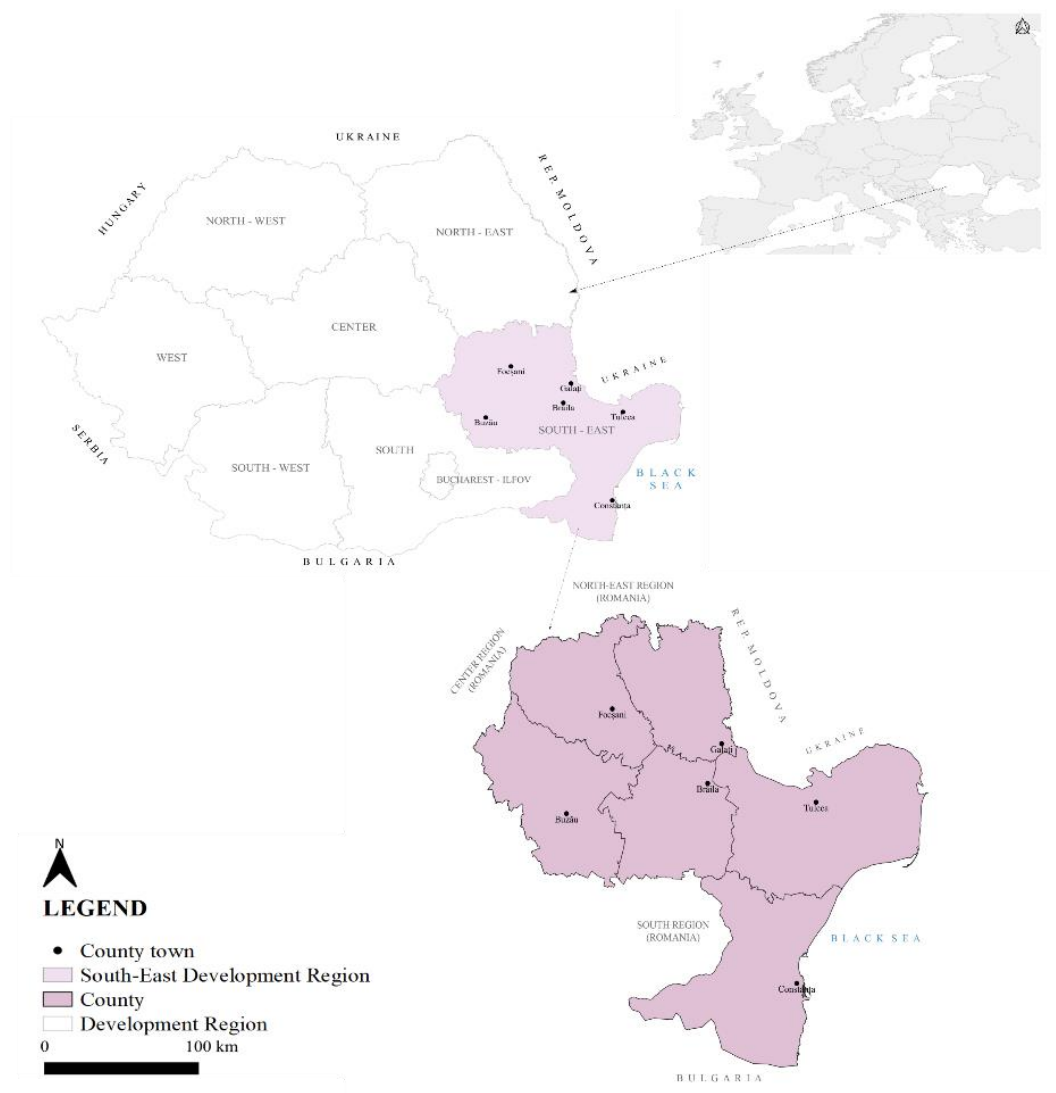

Figure 1. Study area - South-East Development Region

The structural analysis of the tourism profit, for the period 2000-2018, started from a database created for each administrative-territorial unit, at the level of four-digit NACE code, from which those specific to tourism were selected (Table 1). The database was used for evolutionary and structural graphical representations, which will allow us to 
identify those tourism sectors that have the biggest contribution to achieving the total tourism profit in this region.

Table 1. NACE tourism codes

\begin{tabular}{|l|} 
Cod CAEN \\
\hline $\mathbf{5 5 1 0}$ \\
$\mathbf{5 5 2 0}$ \\
$\mathbf{5 5 3 0}$ \\
$\mathbf{5 5 9 0}$ \\
$\mathbf{7 9 1 1}$ \\
$\mathbf{7 9 1 2}$ \\
$\mathbf{7 9 9 0}$ \\
$\mathbf{9 1 0 2}$ \\
$\mathbf{9 1 0 3}$ \\
$\mathbf{9 1 0 4}$
\end{tabular}

\section{Activity type}

Hotels and similar accommodation

Holiday and other short-stay accommodation

Camping grounds, recreational vehicle parks and trailer parks

Other accommodation

Travel agency activities

Tour operator activities

Other reservation service and related activities

Museums activities

Operation of historical sites and buildings and similar visitor attractions

Botanical and zoological gardens and nature reserves activities

\section{RESULTS}

Analyzing the graphs in Figure 2, we can observe the evolution of the total profit obtained at the level of territorial administrative units in which tourism activities are carried out, for the period 2000-2018 (Figure 2A). Also, one can observe the evolution of the profit obtained only from the tourist activities and its share in the total profit, from 2000 to 2018 (Figure 2B).
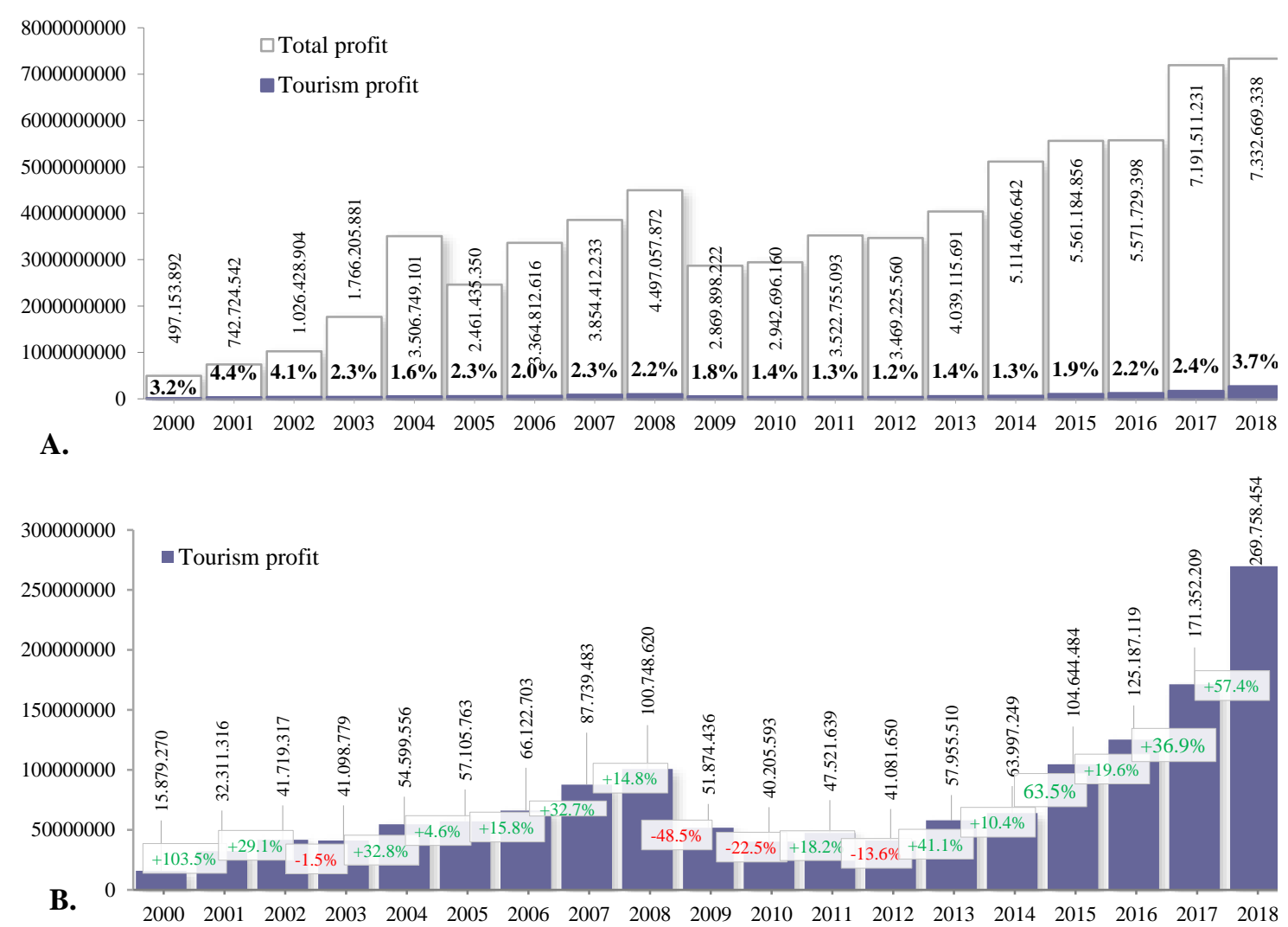

Figure 2. A. Evolution of the total profit from the administrative-territorial units with tourism sector in the South-East Development Region, Romania and the share of tourism

B. The evolution of the tourism profit from the administrative-territorial units with the tourism sector in the South-East Development Region, Romania Source: Project UB 1423 
The total profit value, in 2000 , was $497.153,892$ ron, the tourism companies having a contribution of $3.2 \%$. In 2001, the total profit registered an increase of approximately $50 \%$, while the tourism profit increased by $103 \%$, this fact is reflected in the value of the share of $4.4 \%$. Until 2004, the value of the total profit is in a continuous increase, reaching $3.506 .749,101$ ron, so that in 2005 it will decrease to $2.461 .435,350$ ron and then gradually increase to 4.497.057,772 Ron, in 2008. From 2000 to 2008, the profit obtained by the companies with tourism activity has increased continuously, from 15.879,270 ron to $100.748,620$ Ron, which means an increase of over 500\%. During this time, the share of tourism profit in total profit varied from year to year. If in 2002, tourism companies contributed $4.1 \%$ to the total profit, in 2004 this share decreased to $1.6 \%$, then to keep around 2.2-2.3\% until in 2008. Against the background of the economic crisis, it is observed that in 2009-2010, the total profit falls below 3.000.000,000 Ron. During the same period, the profit from tourism decreases very much, with about $48 \%$ in 2009 compared to 2008 and with about $22 \%$ in 2010 compared to 2009 , reaching a value of 40.205,593 Ron. During the crisis and post-crisis period, tourism companies have considerably reduced their contribution to the total profit of the territorial administrative units. Since 2013, when the value of the total profit exceeds the threshold of 4.000.000,000 Ron, there is a continuous increase, in 2014 exceeding the sum of 5.000.000,000 Ron, and in 2018 reaching the value of 7,332,669,338 Ron. And the tourism profit follows the same trend, increasing in 2011, then decreasing by more than $13 \%$ in 2012, and from 2013 to register a continuous increase, again exceeding the threshold of 100.000,000 Ron, in 2015 and reaching at the value of 269.758,454 Ron, in the year 2018. If in 2012, the share of tourism activities in total profit was $1.2 \%$, it gradually increases, exceeding $2 \%$, in 2016 , so that in 2018 it will reach $3.7 \%$.

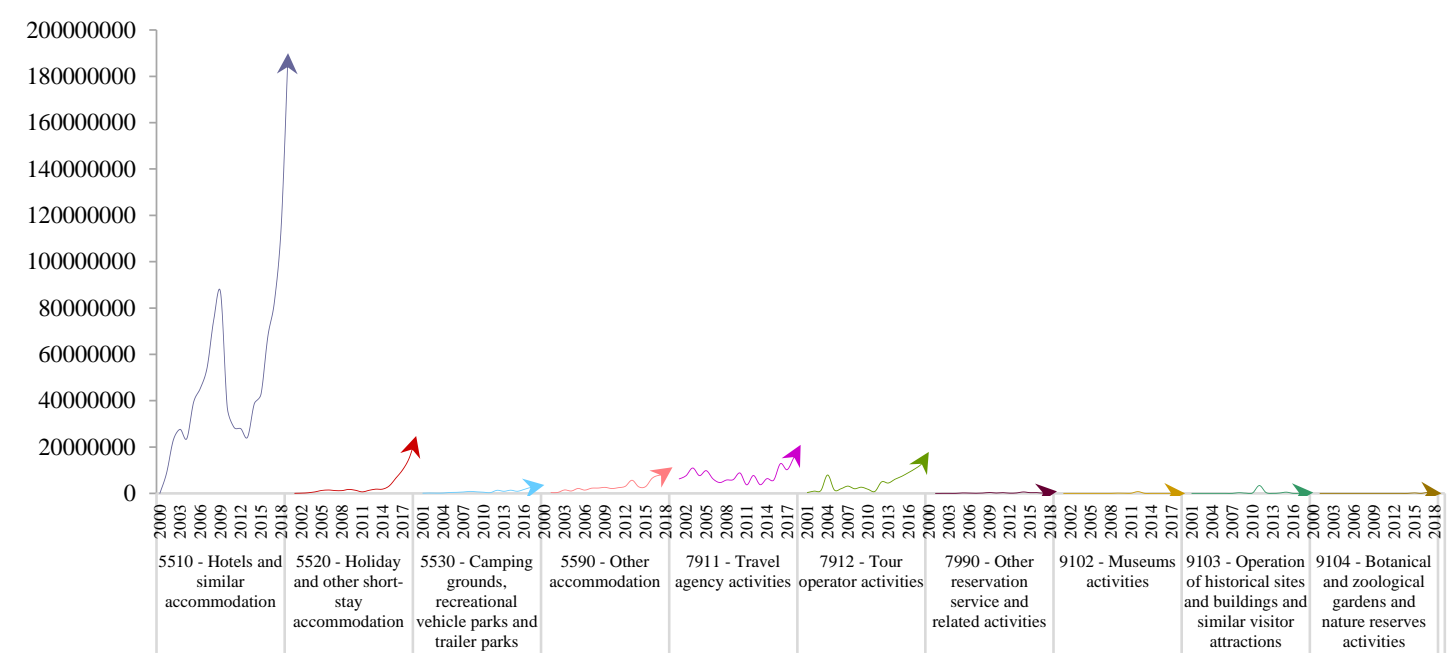

Figure 3. Evolution of tourism profit on 4-digit NACE codes Source: Project UB 1423

Analyzing the evolution of the tourism profit on 4-digit NACE codes (Figure 3), it can be observed that, at the level of the NACE code 5510 (Hotels and similar accomodation), the highest profit of all the tourist activities practiced in the South East Development Region is recorded.

In the period 2000-2008, the profit corresponding to this NACE code increases from $8.812,030$ Ron to $86.624,983$ Ron. In 2009 , the profit from hotel activities decreases to 
36.973,559 Ron and continues to decrease until 2012, when it reaches the value of 24.253,768 Ron, followed by a continuous increase from 2013 to 2018, when it reaches the value of 190.006,826 Ron. For NACE code 5520 (Holiday and other short-stay accommodation) a lower profit value is observed, varying as follows: in the period 20002005 it increased from 31.950 Ron to 1.466,005 Ron; in 2006 and 2007 it decreased, so that in 2008 it would increase to 1.709,923 Ron. After 2011, the profit begins to grow significantly, reaching in 2018 the value of 24.760,902 Ron.

The NACE code 5530 (Camping grounds, recreational vehicle parks and trailer parks) registers profit with large fluctuations during the studied period. In 2000, the profit was 80.338 Ron and almost doubled in 2001, so that in 2002 it would fall slightly. From 2003 to 2007 the profit corresponding to this code increases to the value of 861.617 Ron, so that afterwards it decreases, for three years, to 326.906 Ron in 2010. In the period 20112014 the value of the profit increases or decreases, from year to year, so that from 2015 it will increase continuously. In 2018, it reached the value of 3.624,991 Ron.

Regarding the NACE code 5590 (Other accommodation) it is noted that the minimum value of the profit was registered in 2000, when it was 339,885 Ron, and the maximum value of $11,278,670$ is in 2018. NACE code 7911 (Travel agency activities) records important profit values. The minimum value of 3.684,790 Ron was in 2010, while the maximum value is in 2018, of 20.953,438 Ron. NACE Code 7912 (Tour operator activities) shows an increase in profit in the period 2000-2003, from 365.606 Ron to 7.937,910 Ron. In 2004, there was a decrease, so that in 2005-2006 the value of profit would go up. NACE code 7990 (Other reservation service and related activities) has profit values ranging from 1,189 Ron, in 2000, to 870,517 Ron, in 2018.

For the NACE code 9102 (Museums activities), a short period of activity can be observed, when profit was registered, between 2008-2012, the maximum value reaching 775,619 Ron, in 2011.

NACE code 9103 (Operation of historical sites and buildings and similar visitor attractions) registered a profit in 2003 , RON 4,122, followed by a three-year non-profit period. In the period 2007-2011, profit was registered again, the highest value of the profit of 3.399,384 Ron being registered in 2010. NACE code 9104 (Botanical and zoological gardens and nature reserves activities), is noted for a short period of only three years (2014 and 2016-2017), in which it registered a profit.

In Figure 4 the shares of the tourist activities grouped by NACE codes are analyzed.

In 2000, the largest share in the profit obtained from tourism was owned by the hotel companies (NACE code 5510), which contributed with $56 \%$, followed by the travel agencies (NACE code 7911) with a share of $39 \%$.

In 2004 , the share of hotel activities in tourism profits increases to $72 \%$. In the second place the travel agencies are maintained (NACE 7911), but their share drops to $18 \%$. The NACE code 5530 remain at 1\%, while other accommodation services (NACE code 5590) increase to $4 \%$ and tour operators (NACE code 7912) increase to 3\%. There is also the contribution of $2 \%$ of the companies of Holiday and other short-stay accommodation (NACE code 5520).

In 2008, the hotel companies (NACE 5510) contributed with $86 \%$ of the profit from tourism. Travel agency activities (NACE code 7911) fall 6\%, Holiday and other shortstay accommodation (NACE code 5520) remain at 2\%, Camping grounds, recreational vehicle parks and trailer parks (NACE code 5530) remain at $1 \%$, Tour operator activities (NACE code 7912) remain at 3\%, and Other accommodation (NACE code 5590) fall to $2 \%$. 
2000

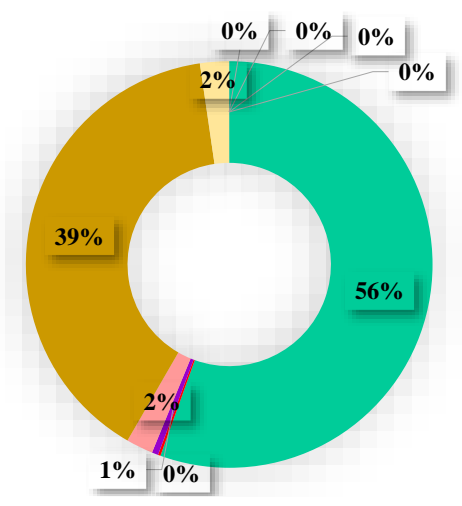

2008

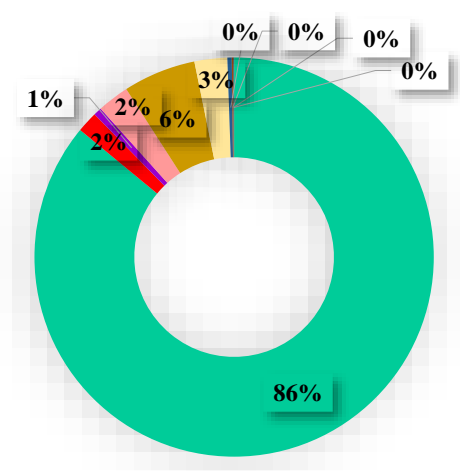

2013



2004

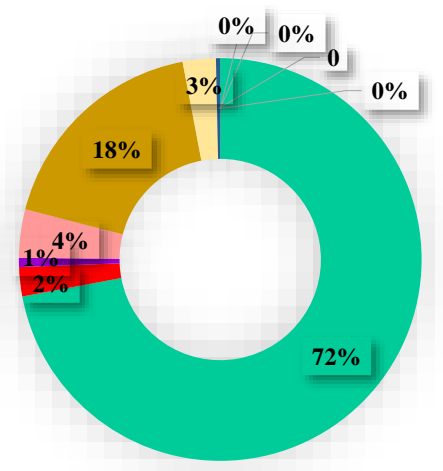

2009



2018

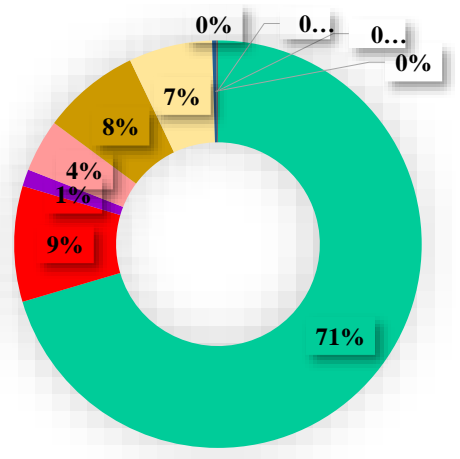

- 5510 - Hotels and similar accommodation

- 5520 - Holiday and other short-stay accommodation

- 5530 - Camping grounds, recreational vehicle parks and trailer parks

5590 - Other accommodation

7911 - Travel agency activities

7912 - Tour operator activities

7990 - Other reservation service and related activities

- 9102 - Museums activities

- 9103 - Operation of historical sites and buildings and similar visitor attractions

- 9104 - Botanical and zoological gardens and nature reserves activities

Figure 4. Share of each NACE code from tourism in total tourism companies

Source: Project UB 1423

In 2009, the NACE code 5510 decrease to $71 \%$, while the travel agencies (NACE code 7911 ) again begin to increase their contribution to $17 \%$. In 2013, hotel companies (NACE code 5510) continue to fall to $67 \%$.

In 2018, the share NACE code 5510 - Hotels and similar accommodation increases to $71 \%$. The second place is taken by the companies that offer accommodation facilities for 
Holiday and other short-stay accommodation (NACE code 5520), which increase by 9\%, while the travel agencies (NACE code 7911) and tour operators (NACE code 7912) fall to $8 \%$, respectively $7 \%$.

\section{CONCLUSIONS}

The analysis of the evolution of the profit obtained by the companies from the South-East Development Region, between 2000-2018, shows that the profit from tourism has a share that varies between $1.2 \%$ and $3.7 \%$ in the total profit from the territorial administrative units with tourism.

Regarding the total profit, the crisis period is highlighted, 2009-2010, when the values decrease a lot, compared to the year 2008, while, the profit from tourism, remains at low values between 2009-2012 and has the lowest shares during 2010-2014.

Structural analysis of tourism profit, by NACE codes, highlighted the highest values of profit that correspond to NACE code 5510. This code holds the highest share in the total tourism profit, while NACE codes 7990, 9102 and 9104 have the lowest shares, close to $0 \%$.

The methodology used, together with other established methodologies [14], [15], [16], [17], can bring an improvement in the elaboration of the management plans at the level of the territorial systems.

\section{REFERENCES}

[1] Braşoveanu A. Metode de analiză structurală a profitului până la impozitare, Studia Universitatis - Revistă Științifică a Universității de Stat din Moldova, vol.2, pp 165-168, 2010.

[2] Nica E., Sima V., Gheorghe I., Drugau-Constantin A. \& Mirica (Dumitrescu) C.O. Analysis of Regional Disparities in Romania from an Entrepreneurial Perspective, Sustainability, vol. 10, 3450, 2018.

[3] Dan M.C. \& Popescu C. Entrepreneurship in the rural areas of Romania. The impact of the 2007-2013 EU funding programmes, Proceedings of the 11th International Conference on Business Excellence, PICBE, Romania, vol. 11, pp 1129-1136, 2017.

[4] Kurowska-Pysz J. Opportunities for Cross-Border Entrepreneurship Development in a Cluster Model Exemplified by the Polish-Czech Border Region, Sustainability, vol. 8, 230, 2016.

[5] Grecu A., Gruia A.K., Marin M., Bănuță M., Olteanu C., Constantin I., Gadoiu M., Teodorescu C., Dobrea C.R. \& Drăghici C.C. Specificity of Sustainable Structural Dynamics of Local Economy in Romanian Tourist Resorts, Sustainability, vol. 11, 7155, 2019;

[6] Marin M., Gruia A.K., Grecu A., Dima C. \& Dobrea C.R. Creative economies role in sustainable development of local economies in Central Region - Romania, Proceedings of the Conference Public recreation and landscape protection - with sense hand in hand..., Czech Republic, pp 78-83, 2019.

[7] Pintilii R.D., Peptenatu D., Ciobotaru A.M., Toma S.G., Grigore A.M., Drăghici C.C., Dobrea R.C., Simion A.G. Andronache I., Teodoresc C. \& Diaconu D.C. Creative economies in Romania - spatial projections and trends, Bulletin of Geography-Socio-Economic, vol 37, pp 95-108, 2017.

[8] Pintilii R.D., Peptenatu D., Draghici C., Irina S. \& Stoian R.,D. Structural Changes in The Entrepreneurial Profile of The Creative Industries in Romania, Proceedings of the 2nd Global Conference on Economics, Management and Tourism (BEMTUR), Czech Republic, vol. 23, pp 1147-1151, 2015. 
[9] Nedelcu A., Tătaru A., Subić J. \& Kuzmand G. The local action group, local development model based on community. Case study - LGA „Land of vineyards and wine“ Vrancea, Procedia economics and finance, vol. 22, pp 706-715, 2015.

[10] Linares L.H., García Betancourt M.E. \& Falcón R.M.C. Sostenibilidad y desarrollo local: procedimiento para la evaluación integrada de los destinos turísticos, Rosa dos Ventos - Turismo e Hospitalidade, vol. 11, pp 84-102, 2019.

[11] Yuliati U., Saeroji A., \& Dadtun Y.S. Heritage tourism development model through an audio visual concept in Lokananta, Surakarta - Indonesia, KnE Social Sciences, U.A.E., vol. 3(5), pp. 532-550, 2018.

[12] Cárdenas-García P.J., Sánchez-Rivero M. \& Pulido-Fernández J.I. Does tourism growth influence economic development?, Journal of travel research, U.S.A., vol. 54(2), pp. 206-221, 2015.

[13] Hontus, A.C., Dinu , T.A. \& Beciu, S. Tourism Analysis in Braila County and its Contribution to Regional Development of South East Region - Romania, $24^{\text {th }}$ International Business Information Management Association Conference, Milan, Italy, Crafting global competitive economies: 2020 vision strategic planning \& smart implementation, vol I-IV, pp. 527-535, 2014.

[14] Andronache I., Fensholt R., Ahammer H., Ciobotaru A.M., Pintilii R.D., Peptenatu D., Drăghici C.C., Diaconu D.C., Radulovic M., Pulighe G., Azihou A.F., Toyi M.S. \& Sinsin B. Assessment of Textural Differentiations in Forest Resources in Romania Using Fractal Analysis, Forests, vol. 8, 2017.

[15] Drăghici C.C., Andronache I., Ahammer H., Peptenatu D., Pintilii R.D., Ciobotaru A.M., Simion A.G., Dobrea R.C., Diaconu D.C., Vișan M.C. \& Papuc R.M. Spatial evolution of forest areas in the northern Carpathian Mountains of Romania, Acta Montanistica Slovaca, vol. 22, pp 95-106, 2017.

[16] Zeleňáková M., Gaňová L., Purcz P., Horský M., Satrapa L., Blišt’an P., \& Diaconu D.C. Mitigation of the Adverse Consequences of Floods for Human Life, Infrastructure, and the Environment, Natural Hazards Review, vol. 18, 05017002, 2017.

[17] Diaconu D.C., Andronache I., Pintilii R.D., Brețcan P., Simion A.G., Drăghici C.C., Gruia K.A., Grecu A., Marin M., Peptenatu D. Using Fractal Fragmentation and Compaction Index in Analysis ofthe Deforestation Process in Bucegi Mountains Group, Romania, Carpathian Journal of Earth and Environmental Sciences, Vol. 14, pp 431 - 438, 2019. 